\title{
Cytogenetic Effect of Radiation in Seed of Oak (Quercus robur L.) Trees Growing on Sites Contaminated by Chernobyl Fallout
}

\author{
By V. N. Kalaev ${ }^{1)}$ and A. K. Butorina
}

(Received 20 $0^{\text {th }}$ July 2004)

\begin{abstract}
The Chernobyl accident was one of the largest man made environmental disasters and had significant consequences for people, animal and plants, particularly on land contaminated by radionuclides. Common oak (Quercus robur L.) is the main forest species on land contaminated by Chernobyl fallout areas in the Voronezh region. Therefore it is very important to know how irradiation of oak trees will affect the quality of oak progeny in future consequently. Cytogenetic characteristics such as mitotic activity, level and spectrum of mitotic disturbances, frequency of the cells with persistent nucleoli in the stages of metaphase, anaphase, telophase and multinuclei in interphase cells were investigated in progeny of common oak (Quercus robur L.) trees subjected to different degrees of radioactive contamination. In progeny growing under the influence of this radioactive contamination we observed variability of such cytogenetic characteristics as mitotic activity. However, the variability of this trait was also connected to fluctuations in the weather. The duration of mitotic stages (which may be connected with disturbance of spindle division formation and absence of cytotomy) also varied. An increase in chromosomal bridges among other types of mitotic abnormalities may be considered a result of increases in the meristematic cells repair activities. Activity of some dormant nucleolus organizer regions was also observed. The level of pathological mitoses increased in particular years and was decreased in others. Thus irradiation induces instability of cytogenetic characteristics in oak progeny that produces a type of "wave kinetics" in the mutation rate. This makes them more sensitive to environmental conditions. Therefore we do not recommend to use the oak seeds collected from irradiated areas for reforestation because undesirable genetic changes may have occurred in them.
\end{abstract}

Key words: Quercus robur L. (common oak), mitotic activity, mitotic disturbances (mitotic pathology), nucleolus, radioactive irradiation, Chernobyl Accident.

\section{Introduction}

The Chernobyl accident led to large-scale radioactive contamination of forest ecosystems in territories of Russian Federation, Belarus and the Ukraine. It was one of the largest man made environmental accidents and had significant consequences for people, animal and plants, particularly for those living on land affected by radioactive fallout. An understanding of such consequences began in the USSR soon after accident in 1986. It followed several lines which included: study of genetical consequences of irradiation for persons participating

\footnotetext{
1) Department of Genetics, Breeding and Evolution Theory, Voronezh State University, Voronezh, Russia, 394006. E-mail: Dr_Huixs@mail.ru
}

in clean-up (the "liquidators") of the Chernobyl disaster and their children; and study of radiation effect on animals and plants (trees and herbaceous). However the results of these investigations have not been published in the Russian scientific literature prior to 1990. At the same time, scientific publications of foreign authors about contamination of soil, air, water, forests, herbaceous plants and doses experienced by populations in many European countries as well as some countries of Asia and America also affected by the Chernobyl fallout were also published in these countries (HAMILTON et al., 1986; BACKE et al., 1987; ElstNer et al., 1987; HofFMAN et al., 1988; Joshi, 1988; BATTISTON et al., 1989; NiCHOLson, 1989 and other). The soviet scientists were more interested in study of genetic consequences from Chernobyl Accident for different organisms such as people, animals and plants (PomerANTSEVA et al., 1990; FrolOV et al., 1993; StEPANOVA, VANYURIKHINA, 1993 and other).

The consequences of the Chernobyl fallout for herbaceous plants has been studied annually since 1986 in Ucraine and Belerus (Frolova et al., 1990; SHEvchenKo, GRINIKH, 1990; DMITRIEVA, 1996; 2000).

A significant variability occurred in plant populations under conditions within the $30-\mathrm{km}$ Chernobyl zone as well as variation in the morphological traits and genetic instability in progeny of the all plants growing in areas contaminated by radionuclides. The consequences of the Chernobyl Accident were investigated more carefully in forest trees. The forests served as the natural filters, which delayed the spreading of the radionuclides. The forest within $30-\mathrm{km}$ zone of Chernobyl particularly suffered. A dose of 8 to $10 \mathrm{Krad}$, experienced by pine forest had lethal effects. Such pine forests were transformed to a "red forest" (BUTORINA et al., 1997). In more distant areas partial pine sterility was observed in 1986 and 1987 (Khromova et al., 1990). The complex investigations of pine forest (morphologic-anatomical, cytological, embryological, electron-microscopical) has been studied by Kozubov et al. within the $30 \mathrm{~km}$ Chernobyl zone since 1986 (KozUBov et al., 1990). Quercus robur and Betula pendula under conditions within the $30-\mathrm{km}$ zone of Chernobyl suffered less than Pinus sylvestris. Significant cytological abnormalities were detected in some oak and birch trees and their progenies and among them were rare types such as persistent nucleoli in oak and disturbances of cell's cytoskeleton in birch (BUTORINA et al., 1997). The consequences of Chernobyl Accident for forest trees were investigated also in contaminated territories of Belarus and Russia (КнотүLEVA et al., 1992; Butorina, Evstratov, 1996). There were many areas in Russia which were suffered also as consequence of Chernobyl accident and Voronezh region was one of them. Therefore the objective of our investigation was to 
reveal the possible genetic effects in progeny of oak trees distant of the Chernobyl accident. The determination of these distant genetic effects of irradiation on oak is important because it answers the question of whether acorns selected from contaminated areas can be used for reforestation. In addition, cytogenetic monitoring of oak progeny provides an objective estimation of environmental state of areas affected by radiation as a result of the Chernobyl accident.

For this study the following cytological parameters were studied in oak plants: the mitotic activity (MA); the speed of cells through each stage of mitosis; the level and spectrum of mitotic disturbances (mitotic pathologies - MP); the frequency of cells having two or more nucleoli per nucleus as reflecting the state of organisms' genetic apparatus.

\section{Materials and Methods}

This study of cytogenetic effects of radiation on oak progeny and the cytogenetic monitoring of the environment using oak as test-object was conduced near the settlement of Starii Kurlak in Anninskii district of the Voronezh region, where soil contamination by the isotope caesium-137 in 1986 reached $3 \mu \mathrm{Ci} / \mathrm{m}^{2}$ (Ecological Informational Bulletin ... , 1993). The settlement of Starii Kurlak is located about $100 \mathrm{~km}$ to the South-West of Voronezh, on the Oksko-Donskoy plain near the Bitiug River, which is part of the left tributary of the river Don. The climate is temperate, with a continental average January temperature of $-9.5^{\circ} \mathrm{C}$ and a July average of $+20.7^{\circ} \mathrm{C}$. Average annual precipitation is 550 to $560 \mathrm{~mm}$ (with a maximum in spring-summer period). The duration of the vegetation growing period (with temperature above $+5^{\circ} \mathrm{C}$ ) is 190 days. The soils are typical chernozem.

The seeds were collected with three experimental areas: Kashara - in 1996 and 1998 (no crop in 1997); Kushelevo - in 1996, 1997 and 1998 (Preservs and Reservs ... , 1983); and Yasnaya Poliana in 1998. These test areas are located between 5 to $7 \mathrm{~km}$ to the south of the settlement of Starii Kurlak. The distance between test sites was 1.5 to $2 \mathrm{~km}$. All experimental areas were very close together and similar in soil and climatic conditions and type of forest species, so that they can be considered as replications. However they differed in the level of Cs-137 contamination because the radionuclide spreading on the soil's irregular surface. The Gamma background radiation levels during seed collections was not higher than 14 to $17(\mathrm{R} / \mathrm{h}$. The level of contamination by $\mathrm{Cs}-137$ was $0.74 \mu \mathrm{Ci} / \mathrm{m}^{2}$ in Kashara in 1995 and $0.15 \mu \mathrm{Ci} / \mathrm{m}^{2}$ in 1998; in Kushelevo $0.15 \mu \mathrm{Hi} / \mathrm{m}^{2}$ in 1995 and $0.07 \mu \mathrm{Ci} / \mathrm{m}^{2}$ in 1998 , and in Yasnaya Poliana 0,23 $\mu \mathrm{Ci} / \mathrm{m}^{2}$ in 1998 . It is possible, that the decrease in soil contamination by $\mathrm{Cs}-137$ is connected with its natural migration into deeper soil layers and is not affected by anthropogenic activities. Therefore we can consider the obtained cytogenetic effects in oak progeny as consequences of the radioactive contamination.

For the investigation we collected 25 acorns which did not show any damage by insects or fungus, from groups of phenotypically normal trees growing in each experi- mental area. In each year of the study the yield of acorns was abundant. The age of oak trees in these natural stands was about 100 years. They grew mixed with pine trees. The oak seed collected in the Usmanskii forest (in district Venevitinovo Training and Research Center of Voronezh State University) were used as controls. Usmanskii is a natural forest area located $30 \mathrm{~km}$ westward of Voronezh. It has the same soil and climatic conditions as the experimental areas. Pinus sylvestris L. is the main forest species here. It grows mixed with common oak, birch and other woody species. Contamination of Usmanskii forest by chemicals and radionuclides did not exceed maximum allowable concentrations (MACs). MACs were determined for the more than 20 different contaminating elements, for example: $\mathrm{Pb}, \mathrm{Zn} \mathrm{Cu}$ and others. Fluctuations in the gamma-background radiation levels were from 10 to $14 \mu \mathrm{R} / \mathrm{h}$. Collection of seeds from the control area was conducted in the same way as it was in the experimental areas. We compared the experimental data on cytogenetic traits in oak seed progeny for 1995 and 1996, because in 1997 and 1998 there were no acorns available from the control area. As a result, statistically significant differences between cytological traits of progenies for these two years were absent. Investigations in these years (1995 to 1998) was characterized by abundant acorns crops in this region. However in 1997 and 1998 most acorns were damaged either by pests or disease.

Root tips of plants were used as the material for investigation. Acorns were grown in moist sand at room temperature and when roots reached a length of 2 to $3 \mathrm{~cm}$ root tips were excised and fixed in an ethanol:acetic acid (3:1) solution. The samples were fixed 22 hours after emergence, when the peak of mitotic activity took place (Butorina, KalaEv, 1998; KAlaev, 2000). Fixed material was kept refrigerated at a temperature of $4{ }^{\circ} \mathrm{C}$. Squash preparations were made and stained by haemotoxilin using a standard method used in our laboratory (BuTORINA, Kalaev, 1998; Butorina et al., 2000). Samples from root tips of 7 to 10 plants were used from both the control and each of the experimental areas. Root tip squashes were examined using a Laboval-4 microscope (Carl Zeiss, Jena) under magnifications of 600 and 1,500 . In each squash the total number of cells (not less than 700), the number of dividing cells in each mitotic stage, and the number of cells with pathological mitoses were recorded. The number of cells with persistent nucleoli on the stages of meta-, anaphase and telophase were also recorded. We determined the mitotic index (the percent of dividing cells out of the total number of meristematic cells examined), the number of pathological mitoses out of the total number of cells and the number of these cells in each of the stages of metaphase, anaphase, telophase; the number of metaphase, anaphase and telophase cells with persistent nucleoli out of the total number of cells in each stage; the distribution of cells in the stages (the parts of anaphase and telophase cells were summarized because differences between these stages are difficult to determine). Classification of pathological mitoses was carried out using the method of Alov (1965, 1976). According to this classification all mitotic pathologies may be divided into 
three groups: 1) mitotic pathologies connected with chromosomal damage (delay of mitosis in prophase; disturbances of spiralization or dispiralization of chromosomes; early disjunction of chromatids; chromosome fragmentation and pulverization; bridges; lagging chromosomes; formation of micronuclei; irregularities of chromosomal segregation; swelling and stickiness of chromosomes). 2) mitotic pathologies connected with injury of mitotic spindle (delay of mitosis in metaphase; C-mitosis; dispersion of chromosomes in metaphase, multipolar mitosis; asymmetric; monocentric mitosis). 3) disturbances of cytotomy (cytokinesis) (delay or absent of cytotomy; precocious cytotomy). The spectrum of pathological mitosis was counted as the number of a particular type of pathology out of the total their number.

The frequency of mitotic disturbances was expressed as a percent from the dividing cells' total number. The number of cells with a different number of nucleoli per nucleus was determined. Microphotographs of persistent nucleoli were made by using system of Videoimage (VideoTest-S.-Pb.). The results were processed statistically using the STADIA software package. The procedure of data grouping and treatment was described by Kulaichev (1996). Cytogenetic characteristics of oak were compared using the following criteria: the frequency of persistent nucleoli and mitotic disturbances, using the nonparametric Van der Varden rank X-test. The mitotic index and the number of cells with $\mathrm{n}$ nucleoli per nucleus were compared using the parametric Student's test, and the variance using the Fisher's test. The parts of cells with different types of mitotic disturbances were compared using of its angular transformation and introducing of Ieit's correction by LAKIN (1990). For detect of correlative dependence parametric coefficient correlation (r) and Spearman's coefficient of rank correlation $\left(\mathrm{r}_{\mathrm{S}}\right)$ were used.

\section{Results}

The results of our investigations of the main mitotic parameters in oak trees progeny from all experimental areas in settlement of Starii Kurlak as compared with control variant were presented in Table 1. All mitotic parameters varied between the different areas (Table 1). It may be a consequence of different degrees of contamination in these areas by radionuclides or due to differences in parental genotypes in their ability to tolerate the radioactivity. The difference of mitotic parameters was observed over several years may be a consequence of fluctuation the weather factors (temperature and moisture). The most important parameter was the "mitotic activity". Mitotic activity can judged by mitotic index, which is determined at peak daily mitotic activity, which is in 22.00 hours (BuTORINA, KALAEV, 1998). It has been shown that mitotic activity in plants in 1996 compared with mitotic activity in 1997 was reduced. This could be caused by decreasing levels of Cs-137 in the soil. However, there was no correlation between these factors because in the experimental area at Kushelevo the mitotic index in meristematic cells of oak plants in 1997 increased to $15.2 \pm 1.4 \%$ and in 1996 it was $13.8 \pm 0.7 \%$ as compared with the control $(13.5 \pm 1.6 \%)$. However, a correlation between the parameters of mitotic index and content of Cs-137 in soil was absent. In 1998 in all the experimental areas oak progeny showed a significant decrease in mitotic index as compared to the control and the same parameters in preceding years $(\mathrm{P}<0,05)$. However, this process can not be considered as a reduction in activity because the low mitotic index was within the limits of variability for this trait (KALAEV, 2000). The peak of mitotic activity may be shifted by the different environmental factors. The possibility of such a phenomenon has already been noticed (BUTORINA, KALAEV, 2000). In this work experimental data varied in different years, however, by comparing

Table 1. - Cytogenetical characteristics of oak progeny from trees growing in areas subjected to radioactive contamination in 1986 as a consequence of the Chernobyl Accident, frequency in \% and content of Cs-137 in the soil in Ci/ $\mathrm{km}^{2}$.

\begin{tabular}{|c|c|c|c|c|c|c|c|}
\hline \multirow[t]{3}{*}{ Cytogenetical indices, $\%$} & \multicolumn{7}{|c|}{ Experimental areas } \\
\hline & \multicolumn{3}{|c|}{ Kushelevo } & \multicolumn{2}{|c|}{ Kashara } & \multirow{2}{*}{$\begin{array}{c}\text { Yasnaya poliana } \\
1998\end{array}$} & \multirow{2}{*}{$\begin{array}{c}\text { Control } \\
1995+ \\
1996\end{array}$} \\
\hline & 1996 & 1997 & 1998 & 1996 & 1998 & & \\
\hline Mitotic index & $13.8 \pm 0.7$ & $15.2 \pm 1.4$ & $11.8 \pm 0.5^{*}$ & $15.0 \pm 1.3$ & $11.5 \pm 0.4^{*}$ & $11.6 \pm 0.4^{*}$ & $13.5 \pm 0.6$ \\
\hline $\begin{array}{l}\text { Mitotic index without accounting } \\
\text { cells in prophase }\end{array}$ & $4.8 \pm 0.2 * *$ & $6.9 \pm 1.3^{*}$ & $6.2 \pm 0.3^{* * *}$ & $5.4 \pm 0.4^{* *}$ & $6.3 \pm 0.4^{* * *}$ & $6.1 \pm 0.3^{* * *}$ & $3.6 \pm 0.2$ \\
\hline Pathologies of mitosis & $1.8 \pm 0.4$ & $3.3 \pm 0.8^{*}$ & $2.6 \pm 0.7^{*}$ & $3.1 \pm 0.6^{* *}$ & $3.0 \pm 0.6 * *$ & $2.8 \pm 0.4 * *$ & $1.4 \pm 0.3$ \\
\hline $\begin{array}{l}\text { Pathologies of mitosis with } \\
\text { accounting of cells in prophase }\end{array}$ & $5.7 \pm 1.2$ & $8.6 \pm 3.5$ & $5.1 \pm 1.5$ & $8.4 \pm 1.6^{*}$ & $5.3 \pm 1.0$ & $5.2 \pm 0.8$ & $5.9 \pm 1.4$ \\
\hline $\begin{array}{c}\text { The frequency of cells with two } \\
\text { nucleoli per nucleus }\end{array}$ & $1.6 \pm 1.6^{*}$ & $3.1 \pm 0.9$ & $6.5 \pm 1.3^{*}$ & $2.5 \pm 0.5$ & $4.3 \pm 0.5^{*}$ & $3.4 \pm 0.5$ & $3.1 \pm 0.3$ \\
\hline The part of cells in prophase & $62.5 \pm 2.1^{*}$ & $56.2 \pm 5.6^{*}$ & $47.2 \pm 1.7 * * *$ & $63.1 \pm 3.1 *$ & $45.8 \pm 2.4 * * *$ & $47.1 \pm 2.5 * * *$ & $72.3 \pm 2.1$ \\
\hline The part of cells in metaphase & $16.6 \pm 0.9 *$ & $19.6 \pm 0.6^{*}$ & $21.4 \pm 1.3 * *$ & $15.8 \pm 1.6$ & $25.3 \pm 1.5^{* * *}$ & $23.4 \pm 1.9 * * *$ & $13.9 \pm 1.1$ \\
\hline $\begin{array}{l}\text { The part of cells in anaphase- } \\
\text { telophase }\end{array}$ & $18.0 \pm 2.2 *$ & $24.0 \pm 5.9^{*}$ & $30.5 \pm 1.8^{* * *}$ & $21.3 \pm 2.3^{*}$ & $30.7 \pm 1.4 * * *$ & $30.1 \pm 1.6^{* * *}$ & $13.7 \pm 1.4$ \\
\hline Content Cs-137 & 0.15 & - & 0.07 & 0.74 & 0.15 & 0.23 & 0.001 \\
\hline
\end{tabular}

Designation:

$*$ - differences with control are significant at $(\mathrm{P}<0.05)$; ** - differences with control are significant at $(\mathrm{P}<0.01)$; *** - differences with control are significant. 
Table 2. - Variance in the mitotic index in oak progeny collected on experimental areas in the vicinity of Starii Kurlak.

\begin{tabular}{|c|l|l|l|}
\hline \multirow{2}{*}{$\begin{array}{c}\text { Experimental } \\
\text { areas }\end{array}$} & \multicolumn{3}{|c|}{ Years Sampled } \\
\cline { 2 - 4 } & 1996 & 1997 & 1998 \\
\hline Kushelevo & 2.9 & 10.2 & 3.2 \\
\hline Kashara & $13.8^{*}$ & - & $1.7^{*}$ \\
\hline Yasnaya poliana & - & - & $2.3^{*}$ \\
\hline Control & 5.7 & & \\
\hline
\end{tabular}

\section{Designation:}

* - differences with control are significant at $(\mathrm{P}<0.05)$.

parameters of mitotic index in different areas in 1996 and 1998 showed a similarity. This provides evidence for a single-direction processes, continuing after radiation contamination in the experiment areas that is effected by the modulating influence of other factors (such as the weather). The fluctuations in mitotic activity highlights this problem. On the experimental area at Kashara in 1996 the variance increased in 1998 decreased below the control in other experimental area, such as Yasnaya Poliana (Table 2).

Differences in the control of this trait were not observed at Kushelevo. This area had the lowest content of Cs-137 in the soil as compared to the other experimental areas.

Considering that maximum level of Cs-137 was noted in 1996 at Kashara, and in 1996 at Yasnaya Poliana we found a correlation between contamination of the area by radionuclides and genetic heterogenity of oak progeny. The more significant fluctuations in progeny heterogenity were observed in the mitotic index. Thus, in populations we can observe the formation of a "wave processes": in one cases a large number of fast growing forms will arise (with high mitotic index) and in others, a slow growing group (with low mitotic index) and their frequency may be reduced to the limits of normal of variability.

The data calculated excluding prophase cells was very interesting. This trait was higher in all experimental areas as compared to the control. It was a result of reducing the number of prophase cells and increasing the number of metaphase and/or anaphase-telophase cells (Table 1). According to the work of AlOV (1976), KASANZEVA (1981), KoltovaYA (2002) the variability of mitotic index calculated excluding prophase cells can be considerated as a disturbance in the processes of formation the spindle apparatus and cytokinesis in dividing cells. Thus the effects on oak progeny of irradiation are seen as changes in the metabolic processes which leads to a disturbance in mitotic apparatus formation. Taking into account changes in the duration of the different stages of mitosis we suggest that mitotic disturbances must be determined depending on how the data in interpreted (including prophase cells or excluding them).

Comparision of experimental and control parameters of pathological mitosis calculated including prophases cells showed they increased in different years on all experimental areas with exception of Kushelevo in 1996. However, an analysis of the mitotic disturbances excluding prophase cells, where disturbances are not observed as a rule, showed an increase in only one experimental area, Kashara in 1996. Comparision of the number of mitotic disturbances both including and excluding prophase cells revealed an increase in 1997 in the experimental area at Kushelevo as compared to 1998 $(\mathrm{P}<0.05)$ and decrease in the number of disturbances in 1998 at Kashara as compared to $1996(\mathrm{P}<0.05)$. The comparision of pathological mitosises frequency in plants on different experimental areas in the same year did not show significant differences, therefore we can not consider that the change in pathological mitoses is explained by dynamic changes of $\mathrm{Cs}-137$ variability into soil. We can agree with the opinion of DMITRIEVA et al. (1999) that irradiation induces an instability of cytogenetic traits in plants. The wave kinetics observed over the 10 to 12 years after the Chernobyl accident is explained by the existence of radiosensitive fraction among the progeny.

Under optimum and approximately similar conditions the radiosensitive fraction is maintained which contains a high frequency of mutations, that is revealed in the progeny. Under unfavourable conditions this fraction is reduced or eliminated which is manifested in a reduction of induced cytogenetical disturbances approaching the levels in the control population (DMITRIEVA, 1996; 2000). It useful to use cytogenetical trait, "mitotic pathologies", calculated both including and excluding prophase cells to determine the level of radiation damage.

Calculation of mitotic pathologies by including prophase cells, in our oppinion, is the preferred method to determine the level of radiation damage because it allows diagnostic of changes in its function, which is seen as an increase in mitotic pathologies and/or a change in the duration of the different stages of mitosis. This may be explained by disturbances of the formation of the spindle fibres or cytokinesis. In order to determine more precisely why the disturbances of mitotic apparatus took place it is necessary to count the number of mitotic pathologies excluding prophase cells and record the distribution cells in the different mitotic 
stages, because it will show if increasing mitotic pathologies took place or if the duration of mitotic stages was changed.

A summarized range of mitotic disturbances is shown graphically on Figure 1 (the data on each point is for all years of the investigation combined). As it can seen in Figure 1, an increase in chromosomal bridges and a decrease in the number of chromosomes delaying in metakinesis took place in oak plants in the all experimental areas compared to the control. A similar spectrum of cytological disturbances were observed in issues, where a repair mechanism for genetic damage was active (AKOPIAN, 1967; SimAKOv, 1983). There is evidence of an increasing repairing ability of the root meristem cells in oak plants affected by irradiation. The comparison of the range of mitotic damage in oak from the different areas did not show significant differences. This confirms the hypothesis of a correlation between cytogenetical effects and soil contamination by Cs-137. Apparently the increased repair abilities and change in cytogenetical features in oak progeny are explained by the activation of genetic systems in an organism after stress. Squashes of root tips of oak plants from different experimental areas showed significant variation in the
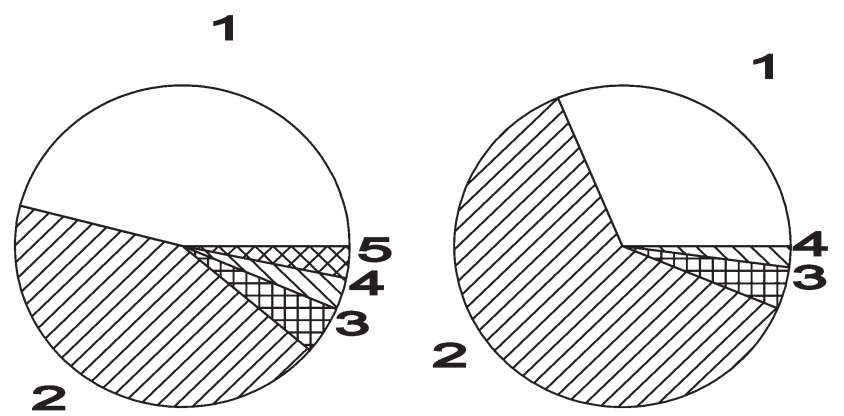

Kushelevo
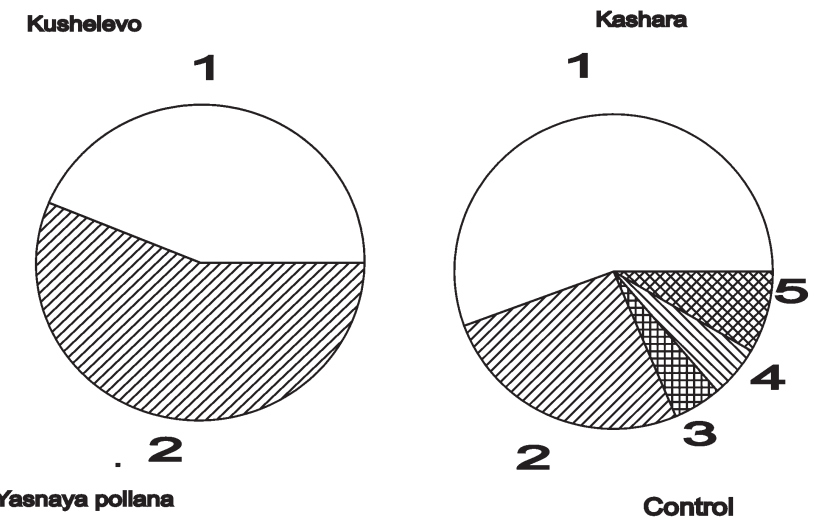

Figure 1. - The spectrum of pathological mitosis in cells of root meristems of oak plants from seeds collected in the experimental areas near Starii Kurlak in 1996 to 1998.

Designates:

1 = delayed chromosomes in metakinesis (Kushelevo - 46.0\%; Kashara - 31.3\%; Yasnaya poliana - 43.8\%; control - 55.6\%).

2 = bridges ( Kushelevo $-42.9 \%$; Kashara $-62.5 \%$; Yasnaya poliana - 56.2\%; control - $25.5 \%$.

3 = delayed chromosomes in anaphase (Kushelevo - 4.8\%; Kashara - 4.2\%; Yasnaya poliana - 0\%; control - 4.9\%).

4 = uncommon pathologies (Kushelevo - 3.2\%; Kashara - 2.1\%; Yasnaya poliana - 0\%; control - 5.3\%); 5 - agglutination of chromosomes (Kushelevo - 3.2\%; Kashara - 0\%; Yasnaya poliana $-0 \%$; control $-8.4 \%$ ). number cells with two nucleoli per nucleus. Variability in this feature may be evidence of activation of latent nucleolus organizer regions. Normally common oak has two pairs of chromosomes with nucleolus organizers regions. If there are more than two nucleoli per nucleus it may indicate an increased metabolic activity. Such mechanisms have been discussed by many authors (Muratova, SEdelniKova, 1999; KalashniK, Haidarova, 1999; KALAEV, KARPOVA, 2003). The frequency of the cells with two nucleoli per nucleus is shown in Table 1. In oak plants from the experimental area at Kushelevo in 1996 the number of cells with two nucleoli per nucleus decreased compared to the controls (in experiment $1.6 \pm 0.5 \%$, in control $3.1 \pm 0.3 \%, \mathrm{P}<0.05)$, and in 1998 the number increased (in experiment $6.5 \pm 1.3 \%$, $\mathrm{P}<0.05)$. It the same year, in two oak plants collected at this site, three cells with five nucleoli per nucleus were found. Such a phenomenon is not normally typical in oak. In 1998 in the experimental area at Kashara the number of cells with two nucleoli per nucleus increased (in experiment $-4.5 \pm 0.5 \%, \mathrm{P}<0.05$ ). Although the frequency of cells with two nucleoli per nucleus in the control sample did not correlate with the other cytogenetical characteristics, there was a negative correlation with the mitotic index $(\mathrm{r}=-0.325, \mathrm{P}<0.05)$ and the number of prophase cells $\left(\mathrm{r}_{\mathrm{S}}=0.185, \mathrm{P}<0.05\right)$ showed a positive correlation with the frequency of mitotic disturbances when calculated including prophase cells $\left(\mathrm{r}_{\mathrm{S}}=0.351\right.$, $\mathrm{P}<0.01)$ as well as excluding them $\left(\mathrm{r}_{\mathrm{S}}=0.185, \mathrm{P}<0.05\right)$. According to Rostova (1999), under favourable conditions the correlation between traits was limited but and increased under stress. Therefore we can suppose that in oak two mechanisms of adaptation to such stress can take place. The first is manifested as a variability in the number of prophase cells (a positive correlation with pathological mitoses $\left(r_{S}=0.231 ; P<0.05\right)$, the second is dependant on activation of the nucleolus organizers regions (which may also be dormant)) because the frequency of cells with two nucleoli per nucleus is in negatively correlated with the number of prophase cells and is positively correlated with the frequency of mitotic disturbances as calculated by excluding prophase cells. Therefore we can suppose that these mechanisms of adaptation are correlated and they compensate for each other. It is possible that after radiation damage of oak, the dormant nucleolus organizers in the progeny become active. In oak seeds persistent nucleoli were observed in the stages of metaphase, anaphase and telophase (Fig. 2 ). The frequency and the number of investigated plants with such nucleoli are shown in Table 3 . The frequency of persistent nucleoli in mitotic metaphase cells was lower than in controls or they were absent in 1996, 1997 and in 1998 differences with controls were not found. The occurrence of persistent nucleoli in oak with a high frequency $(37 \%)$ was detected in meristematic cells of two-year old seedlings from seeds collected within a 30 $\mathrm{km}$ zone of the Chernobyl power station in 1986. This phenomenon consisted of puffing of the chromosomes under conditions of radiation thus expressing of many rDNA genes (Butorina, IsAKov, 1989; Butorina et al., 1997). However, later persistent nucleoli were also detected in peak of mitotic activity in oak growing under 

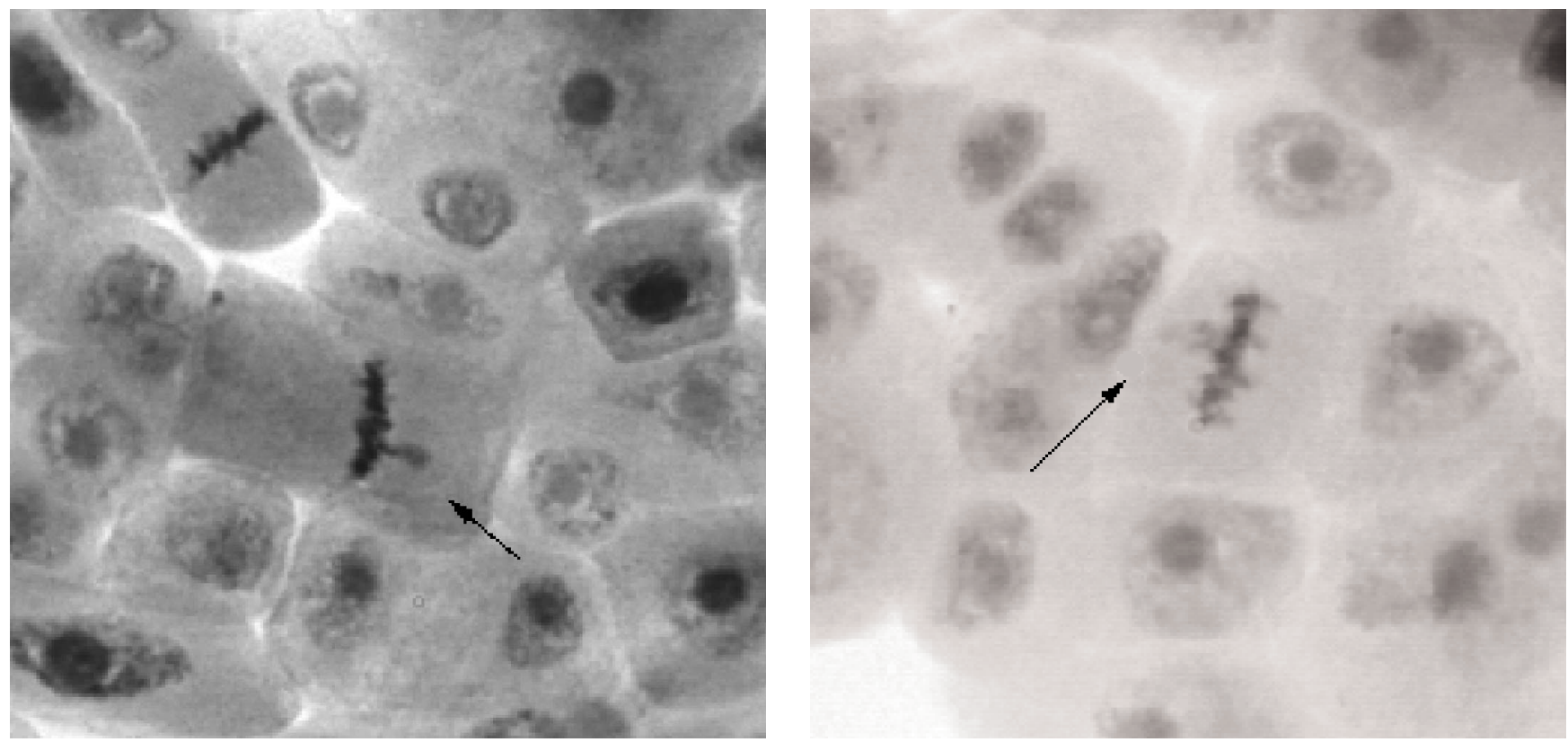

Figure 2. - Persistent nucleoli in mitotic cells of root meristems in plants of oak from seeds collected in the experimental areas near Starii Kurlak in 1996 to 1998.

unstressful conditions (BUTORInA, KAlaEv, 1998) but their frequency was low.

\section{Discussion}

The effects of irradiation from the Chernobyl accident on oak progeny growing in the Voronezh region was studied for the first time. Quercus robur is one of the most important forest species in the Voronezh region and it is important to know what genetic consequences may occur in progeny of irradiated trees in determine their future use in reforestation. The problem of the effects of irradiation has been studied with respect to people and animal at different levels including cells, organisms, and populations. It has been shown that cultivated cells of irradiated organisms showed a high level genomic instability. This irradiation- induced genome instability is characterized by a high frequency of chromosomal and gene mutations, an increased number of micronuclei, increased micro- and minisatellite variability, increased malignant transformations, and increased clonal heterogeneity. In these cells high rates of gene amplification and disturbance of cell differentiation were also observed (KRONENBERG, 1994; LOEB, 1994; Morgan et al., 1996; Litlle, 1998; JAMALI, RotT, 1996; Meyn, 1997; TrotT, TeIBE, 1998; Limoli et al., 1999).

Studying cytogenetic after-effects in irradiated plants showed a variability and lability in the cytomorphologic traits after acute irradiation and after low level irradiation, which induced genome instability (PozolotinA, $1996 ; 2003)$. In some plant populations increases in chromosomal aberrations was recorded. The number of aneuploids and organisms with B-chromosomes increased in such populations (DMITRIEVA, 1996; 2000). In other irradiated populations a decrease of chromosomal disturbances took place relative to the control population and then a "wave kinetic" type of mutagenesis was observed. The essence of the wave kinetics is alteration of increasing and decreasing of mutation frequency in particular populations. The causes of this phenomenon is not known. It is believed that it could be a response to the short-term acute or long-term weak

Table 3. - The frequency of persistent nucleoli (PN) in metaphase cells of root meristem of oak plants from seeds collected in the experimental areas in the vicinity of Starii Kurlak.

\begin{tabular}{|c|l|l|l|l|l|l|}
\hline \multirow{2}{*}{$\begin{array}{c}\text { Experimental } \\
\text { area }\end{array}$} & \multicolumn{3}{|c|}{ PN / total number of samples } & \multicolumn{3}{c|}{ Frequency of PN, \% } \\
\cline { 2 - 7 } & \multicolumn{3}{|c|}{ Years Sampled } & \multicolumn{3}{c|}{ Years Sampled } \\
\cline { 2 - 7 } & 1996 & 1997 & 1998 & 1996 & 1997 & 1998 \\
\hline Kushelevo & $0 / 7$ & $2 / 7$ & $15 / 15$ & 0 & $6.2 \pm 4.2^{*}$ & $10.0 \pm 2.0$ \\
\hline Kashara & $2 / 8$ & - & $11 / 11$ & $3.0 \pm 2.0^{*}$ & - & $13.8 \pm 3.1$ \\
\hline
\end{tabular}

Designation:

* - differences with control are significant at $(\mathrm{P}<0.05)$. 
influence by ionizing radiation, leading to radiationinduced genome instability. There are two possible main mechanisms of its origin: 1) hereditary variation, conditioned by an increase of mobile genetic element induction; or, 2) conformational genome reconstructions changing the activity of genetic regulation of the cell differentiation processes. The effect of such mechanisms will depend on the intensity of biotic and abiotic environmental factors on the affected organisms (PozOLOTINA, 1996; 2003). Our publication describes the cytogenetic consequences of radioactive contamination of oak progeny in areas where the gamma-background were already normalized. However, it is very important for resolve the question of the possibility of using the seeds from trees growing on contaminated areas for reforestation and also to provide a method for cytogenetic monitoring of areas affected by Chernobyl fall-out using progeny of common oak. We observed effects of radiation-induced genome instability in progeny of oak trees growing within $30 \mathrm{~km}$ zone of Chernobyl soon after accident in autumn 1986. Such effects were dramatic (BUTORINA et al., 1997). However our present investigations conducted through more than 10 years after Chernobyl Accident in the districts of Voronezh region affected by Chernobyl fallout also showed the genomic instability in oak plants from seeds gathered from these districts. It is manifested as a variation in mitotic activity (the variability if this trait depended on fluctuations in weather conditions) as a variability in the duration of the mitotic stages which was affected by disturbances in spindle formation and cytokenesis following irradiation. In spite of normalization of the background gamma radiation in the experimental areas in oak progeny, the higher incidence of chromosomal bridges was observed as evidence of the cells increased repair activities. The occurrence of the cells with 4 to 5 nucleoli instead of the normal 1 to 2 suggests that dormant nucleolus organizer regions were activated.

The low frequency of persistent nucleoli in oak progeny under conditions of gamma-background normalization provides evidence of their metabolic processes normalization.

However it has also been shown that in some years the level of pathological mitosis increased. These data are in agreement with the concept of a wave kinetics of type mutation process in plants following irradiation. On our scale of genetic sensitivity to stress factors (Butorina, KalaEv, 2000), cytogenetic effects in progeny caused by irradiation can be estimated. In 1996 and 1998 in the experimental area of Kashara damage to the genetic apparatus was estimated as medium because the number of pathological mitoses increased and mitotic activity was changed. In other experimental areas such effects were reduced.

Because in the all experimental areas the duration of different mitotic stages was changed we may suppose that it is a more sensitive criterion for estimating the stress influence on species with small number of chromosomes. From the results of the present investigation the conclusion can be drawn that by using of oak progeny from districts subjected by radioactive contamination for aim of reforestation, even after ten years, is not desirable or such seeds must be used carefully (only after examining their cytological parameters) for reforeststation, because such seed material can result in poor quality forest stands.

\section{Acknowledgements}

This study was supported by a grant from the President of Russian Federation for young Russian Scientist and Leading Scientific Schools of Russian Federation "Cytogenetical Reactions of Woody Plants (on example of leafbearing) on Stress Conditions Depended on Anthropogenic Contamination and Estimate of Genotoxic Environmental for Human by Cytogenetical Traits of Wood Plants" (Grant MK-2587.2004.4).

The authors would like to thank the Head of Chair of Anatomy and Physiology of Human and Animal of Belgorod State University, Professor E. A. LIPUNOvA and Assistant Professor M. Yu. SKoRKINA for possibility to work with the "VideoTesT" system.

\section{Literature}

Akopian, E. M. (1967): Influence of different types of ionizing radiation on chromosome aberrations origin in Vicia. Russian J. of Genetics 3 (5): 45-51.

Alov, I. A. (1965): Pathology of mitosis. Bulletin of Medicine Science USSR 11: 56-66. (in Russian)

Alov, I. A. (1976): The Problems of Mitotic Pathology, pp. 40-66 in Cytologia. Vol. 3. Nauka. Moskow. (in Russian)

BACKe, S., H. BJerke, A. Rudjord and A. UGeltsveit (1987): Fall-out pattern in Norway after the Chernobyl accident estimated from soil samples. Radiat. Prot. Dosim. 18 (2): 105-107.

Battiston, G. A., S. Degetto, K. Gerbasi and G. SbrigNADELLO (1989): Radioactivity in mushrooms in northeast Italy following the Chernobyl accident. J. Environmental Radioact. 9 (1): 53-60.

Butorina, A. K. and V. N. Kalaev (1998): Diversity of Cytological Characteristics in Oak Under Normal Conditions, pp. 46-48 in Diversity and Adaptation in Oak Species. Edited by S. Schlarbaum, Proceedings of a Conference of IUFRO Working Party 2.08.05 held Oct. 12-17, 1997, College of Agricultural Sciences, The Pennsylvania State University, University Park, Pennsylvania, U.S.A. Pennsylvania,

Butorina, A. K. and N. Evstratov (1996): The first detected case of amitosis of pine. Forest Genetics 3 (3): 137-139.

Butorina, A. K. and Yu. N. Isakov (1989): Puffing of chromosomes in metaphase - telophase of mitotic cycle in common oak. Reports of Academy Sciense USSR 308 (4): 987-988. (in Russian)

Butorina, A. K. and V. N. Kalaev (2000): Analysis of Sensitivity of Different Criteria in Cytogenetic Monitoring. Russian Journal of Ecology 31 (3): 186-189.

Butorina, A. K., V. N. Kalaev, T. V. Vostrikova and O. E. MYagkova (2000): Cytogenetic characteristics of some wood plant species under conditions of anthropogenic contamination in Voronezh. Tsytologia. 42 (2): 196-201. (in Russian)

Butorina, A. K., N. E. Kosichenko, Y. N. Isakov et al. (1997): The effects of irradiation from the Chernobyl nuclear power plant accident on the cytogenetic behaviour and anatomy of trees, pp. 211-226, in Cytogenetic studies of forest trees and shrub species, edited by $\mathrm{Z}$. BoRZAN, Hrvatske Sume, Zagreb. 
DMITRIEVA, S. A. (1996): The study of adaptation of natural plant populations to chronic irradiation caused by the CNPP accident. Cytol. and Genetics. 30 (4): 3-14.

Dmitrieva, S. A., V. I. PARfenov and T. O. DAVIDChuK (1999): Cytogenetical monitoring of natural plant populations in connection with influence fall-out after Chernobyl Accident. Tsytologia. 41 (12): 1062-1063. (in Russian)

Dmitrieva, S. A. (2000): Karyology of flora Belarus: Author's Abstract of Doct. Diss. Biol. Sci. Minsk. (in Russian)

Ecological Information Bulletin About State Problems and Prognosis of Protection Environment in Region (1993): Publisher of Voronezh State University, Voronezh. (in Russian)

Elstner, E. F., W. Holl, E. Lengfelder and H. Ziegler (1987): Natural and Chernobyl-caused radioactivity in mushrooms, mosses and soil-samples and defined biotops in SW Bavaria. Decologia 73 (4): 553-558.

Frolov, V. M., N. A. Peresadin, E. F. Safonova and I. R. BASILYAK (1993): Cytogenetic disturbances in persons participating in liquidation of the Chernobyl Disaster aftereffects and constantly living in the ecologically unfavorable regions. Cytology and Genetics 7 (4): 14-19.

Frolova, N. P., O. N. Popova and A. I. Taskaev (1990): Monitoring of sees of chronically irradiated natural population of Plantago lanceolata L. viability of seeds. Radiation Biology 30 (3): 297-299. (in Russian)

Hamilton, E. I., B. Zon and R. J. Clifton (1986): The Chernobyl accident - radionuclide fallout in SW England. Sci. Total Environ. 57: 231-251.

Hoffman, F. O., E. Amaral, D. A. Mohrbacher and E. J. DEMING (1988): The comparision of generic model predictions with Chernobyl Fallout Data on the transfer of radioiodine cover the Air-Pasture-Cow-Milk Pathway. J. Env. Radioact. 8 (1): 53-71.

JAMALI, M. and K. R. T. RоTT (1996): Increased micronucleus frequency in the progeny of irradiated Chinese hamster cells. Int. J. Radiat. Biol. 69: 301-307.

JoshI, S. R. (1988): The fallout of Chernobyl radioactivity in Central Ontario, Canada. Env. Radioact. 6 (3): 203-212.

KaLAEv, V. N. (2000): Cytogenetical monitoring of environment contaminations with using of plant test-objects. Author's Abstract of Cand. Diss. Biol. Sci. Voronezh. (in Russian)

Kalaev, V. N. and S. S. Karpova (2003): The influence of air pollution on cytogenetic characteristics of birch seed progeny. Forest Genetics 10 (1): 11-18.

KAlashniK, N. A. and T. G. Haidarova (1999): Nucleolus organizers of chromosomes as adaptive elements of coniferous species, pp. 79-80 in Assessment Method of Forest Ecosystem Status and Sustainability, Abstracts Workshop (August 8-13, 1999, Krasnoyarsk, Russia), Krasnoyarsk.

KAZANTSEVA, I. A. (1981): Mitotic pathology in human tumour. Nauka, Novosibirsk. (in Russian)

Khotyleva, L. V., L. A. Dylenok, A. P. Jatsevich and G. G. GONCHARENKo (1992): Effects of a high radiation level on the frequency of chromosome aberration in spruce (Picea abies (L.) Karst. Doklady Academii Nauk Belarusi 36 (9-10): 842-845. (in Russian)

Khromova, L. V., M. G. Romanovsky and V. A. DukHarev (1990): Partial pine sterility in 1986 and 1987 within the zone of Chernobyl accident. Radiation Biology 30 (4): 450-457. (in Russian)
Koltovaya, N. A. (2001): Checkpoint-control in yeast Saccharomyces cerevisia: Preprint of United Institute of Nuclear Research. Dubna. (in Russian)

Kozybov, G. M., A. I. Taskaev, E. I. Ignatenko, V. A. Artemov, E. K. Ostapenko, N. V. Ladanova, S. V. KuziVANOVA, V. A. KozLOV and V. B. LARIN (1990): Influence of radiation on coniferous forests in district of accident on Chernobyl NPP. Komi Science Center Ural Department of Academy Nauk of USSR, Krasnoyarsk. (in Russian)

KronenBerg, A. (1994): Radiation-induced genomic instability. Int. J. Radiat. Biol. 66: 603-609.

Kulaichev, A. P. (1996): The methods and the ways of data analysis in operation medium (surrounding) Windows. Stadia 6.0. Informatics and Computers, Moskow. (in Russian)

LAKIN, G. F. (1990): Biometry. Visshaya Shkola, Moskow. (in Russian)

Limoli, C. L., J. J. Corcoran, J. R. Milligan, J. F. Ward and W. F. Morgan (1998): Critical target and dose-rate response for the induction of chromosomal instability by ionizing radiation. Radiat. Res. 151: 677-685.

LiTTLE, J. B. (1998): Radiation-induced genomic instability. Int. J. Radiat. Biol. 74: 663-671.

LoeB, L. A. (1994): Microsatellite instability: Marker of mutator phenotype in cancer. Cancer Res. 54: 5059-5063.

MEYN, M. S. (1997): Chromosome instability syndromes: lesions for carcinogenesis, pp. 72-148 in Genetic instability and tumorigenesis, edited by M. B. KASTAN, Springer Verlag, Berlin.

Morgan, W. F., J. P. Day, M. I. Kaplan, E. M. McGhee and C. L. Limoli (1996): Genomic instability induced by ionizing radiation. Radiat. Res. 146 (2): 247-258.

Muratova, E. N. and T. S. Sedelnikova (1999): Chromosome aberration and polymorphism of nucleolar locuses as the factors of coniferous resistance under extremal forest-growing conditions, pp. 116-117 in Assessment Method of Forest Ecosystem Status and Sustainability, Abstracts Workshop (August 8-13, 1999, Krasnoyarsk, Russia), Krasnoyarsk.

NichOLSON, K. W. (1989): The deposition, resuspension and weathering of Chernobyl derived material in the UK. J. Raidat. Prof. 9 (2): 113-119.

Pomerantseva, M. D., B. V. Festov, L. K. Ramaja, V. A. Shevchenko and A. V. Chekhovich (1990): Genetic disturbances in laboratory mice exposed in the Chernobyl APP area. Cytology and Genetics 24 (4): 46-50.

Pozolotina, V. N. (1996): Adaptation processes in plants under conditions of irradiation influence. Russian J. of Ecology 27 (2): 110-116.

Pozolotina, V. N. (2003): Remote effects of irradiation in plants. Akademkniga, Ekaterinburg. (in Russian)

Preservs and Forest Reserves of Voronezh Region (1983): Centre Chernozem Publishing House, Voronezh. (in Russian)

Rostova, N. S. (1999): Variability of morphology traits system correlation. I. Natural populations Leucanthemum vulgare (Asteraceae). Botanical Journal. 84 (11): 50-66. (in Russian)

Shevchenko, V. V. and L. I. Grinikh (1990): Cytogenetic effects in natural Crepis tectorum populations subjected to chronic irradiation within the zone Chernobyl accident induction of chromosome aberration during the first two years after the accident. Radiation Biology 30 (6): 728-729. (in Russian) 
Simakov, E. A. (1983): About post-irradiation reparation of cytogenetic damages in plantlets of different potatos' forms. Radiobiology 23 (5): 703-706. (in Russian)

StePANOva, E. I. and E. A. VANYURIKHINA (1993): Clinical and cytogenetic characterization of children whose fathers suffered from acute radiation sickness of the $1^{\text {st }}$ and $2^{\text {nd }}$ stages due the accident at the Chernobyl
Nuclear power plant. Cytology and Genetics 27 (4): 10-13.

Trott K. R. and A. TeIBe (1998): Lack of specificity of chromosome breaks resulting from radiation-induced genomic instability in Chinese hamster cells. Radiat. Environ Biophys. 37: 171-176.

\title{
Identification of Atractylodes japonica and A. macrocephala by RAPD analysis and SCAR Markers
}

\author{
By M. K. $\mathrm{HUH}^{1), *)}$ and K. H. BANG ${ }^{2)}$
}

(Received 24 ${ }^{\text {th }}$ April 2005)

\begin{abstract}
The Chinese plant, "Packchul", (Atractylodes japonica or A. macrocephala), is a very important Chinese medicinal herb plant and is called Sabju in Korea. The levels of the active components are different between these two species, but these medicines are sold in Korean herbal markets without discrimination. This study was carried out to develop a method that could be used to discriminate between $A$. japonica and A. macrocephala based on molecular markers. To discriminate between A. japonica and A. macrocephala, RAPD analyses were used to develop SCAR markers. Eighteen species-specific RAPD bands were obtained from 52 OPERON and URP primer sets. Two SCAR markers were developed from these RAPD clones. Both SCAR markers were cloned into pGEM-T-Easy vectors and then subjected to nucleotide sequence analysis and designated $A j R 1$ $(1,117 \mathrm{bp})$ and $A m R 1$ (1,325 bp). These two markers were sufficient to discriminate between samples of A. japonica and A. macrocephala.
\end{abstract}

Key words: Atractylodes japonica, A. macrocephala, RAPD, SCAR.

\section{Introduction}

"Packchul", which is commonly called atractylodis rhizoma, white atractylodes rhizome, or simply atractylodes, is used as a Chinese herbal medicine. Packchul consists of two species with the botanical names of Atractylodes japonica Koidz and A. macrocephala Koidz. It has been reported that Packchul has various health benefits, such as regulating the function of the stomach, replenishing vigor, strengthening the spleen, stopping sweating, and preventing miscarriage (SАKАмото et al., 1996).

1) Department of Molecular Biology, Dongeui University, Busan 614-714, Korea.

$\left.{ }^{2}\right)$ Division of Ginseng \& Medical Crops, National Institute of Crop Science, RDA, Suwon 441-857, Korea.

*) Corresponding author: MAN KYU HuH, Fax: +82-51-890-1521, Tel: +82-51-890-1529, E-mail: mkhuh@deu.ac.kr
The Korean botanical name "Sabju" represents the genus Atractylodes of the family Compositae and is divided into two types, "Packchul" and "Changchul". In Korean pharmacopoeia. Packchul is defined as the rhizome and peeled rhizome of $A$. japonica and Changchul is defined as those of A. lancea (Thunb.) DC. or A. chinensis Kitamura. In the Chinese pharmacopoeia, however, Packchul includes not only A. macrocephala, but also includes $A$. ovata DC. and Changchuls, which includes A. japonica, A. lancea, and A. chinensis (KIM et al., 1998). This discrepancy has caused a confusion and difficulty in the use of these herbal medicines.

During the last decade several novel DNA markers have been developed for genome analysis. Among the types of molecular markers, "random amplified polymorphic DNA" (RAPD) techniques have greatly improved detection methods since their first reported use in 1990 (Williams et al., 1990; NiCESE et al., 1998).

The RAPD technique is sensitive to reaction conditions, which results in poor reproducibility. To overcome the problems associated with RAPD and to improve their utility in marker-assisted selection, longer primers have been developed from RAPD fragments (PARAN and MiCHELMORE, 1993). These longer primers generate a "sequence-characterized amplified region" (SCAR), which can be particularly useful to follow the inheritance of the marked region of the genome. SCAR markers are preferred over RAPD because they detect only a single locus, their amplification is less sensitive to reaction conditions, and they can potentially be converted into allele-specific markers. SCAR markers have been developed for crops (DENG et al., 1997; HERNANDEZ et al., 1999; ARDIEL, 2002). The conversion of a linked marker to SCAR has been applied successfully in a number of cases involving RAPD (NAQVI and CHATTOO, 1996; BARRET et al., 1998; LAHOGUE et al., 1998).

In Atractylodes species, several studies using RAPD and RFLP analyses have been reported but the use of RAPD analysis and SCAR markers to discriminate between the species has not been reported. 